\title{
ANALISIS BUKU AJAR BIOLOGI KELAS X SEMESTER GANJIL BERDASARKAN KATEGORI LITERASI SAINS CHIAPPETTA DAN FILLMAN
}

\author{
Nurul Laili Fitriyani \\ Program Studi Pendidikan Biologi Universitas Sebelas Maret Surakarta \\ Jl. Ir. Sutami No 36 Kentingan, Jebres, Surakarta \\ Email: nurul.lailifitrii@gmail.com \\ Riezky Maya Probosari \\ Program Studi Pendidikan Biologi Universitas Sebelas Maret Surakarta \\ Jl. Ir. Sutami No 36 Kentingan, Jebres, Surakarta \\ Email: riezkymaya@fkip.uns.ac.id \\ Suciati \\ Program Studi Pendidikan Biologi Universitas Sebelas Maret Surakarta \\ Jl. Ir. Sutami No 36 Kentingan, Jebres, Surakarta \\ Email: suciati.sudarisman@yahoo.com
}

\begin{abstract}
Abstrak
Penelitian ini bertujuan untuk mengetahui hasil analisis Buku Ajar Biologi untuk SMA Kelas X Semester Ganjil berdasarkan kategori literasi sains Chiappetta dan Fillman. Penelitian ini merupakan penelitian kualitatif dengan pendekatan analisis isi. Objek penelitian adalah dua buku teks biologi kelas $\mathrm{X}$ dari dua penerbit berbeda pada materi semester ganjil. Teknik pengambilan objek penelitian menggunakan purposive sampling. Pengumpulan data melalui analisis oleh petugas koding secara mandiri pada unit-unit buku teks biologi kelas X. Reliabilitas data penelitian ini menggunakan indeks kesepakatan Kappa. Analisis data menggunakan deskriptif kualitatif. Hasil penelitian menunjukkan bahwa muatan empat dimensi literasi sains pada kedua buku teks biologi kelas $\mathrm{x}$ yang dianalisis memiliki perbandingan sebaran tidak merata, dengan dominasi kategori sains sebagai batang tubuh pengetahuan. Hasil analisis literasi sains Buku A yaitu: sains sebagai batang tubuh pengetahuan sebesar 90,77 persen; sains sebagai jalan penyelidikan sebesar 5,56 persen; sains sebagai cara berpikir sebesar 3,1 persen; serta interaksi sains dengan teknologi dan masyarakat sebesar 0,53 persen. Hasil analisis literasi sains Buku B yaitu: sains sebagai batang tubuh pengetahuan sebesar 69,70 persen; sains sebagai jalan penyelidikan sebesar 12,47 persen; sains sebagai cara berpikir sebesar 2,78 persen; serta interaksi sains dengan teknologi dan masyarakat sebesar 15,05 persen.
\end{abstract}

Kata kunci: analisis isi, buku ajar biologi, literasi sains 


\begin{abstract}
The aim of this research is to analyze the first semester of biology textbooks of senior high school first grade based on Chiappetta and Fillman category of science literacy.The research is qualitative research using content analysis. Object of the research are two biology textbooks of senior high school first grade by different publisher, using the first semester of each books. Sampling technique used in this research is purposive sampling. Data collection in this research done by two coder who collecting data of two biology textbooks of senior high school first grade independently. Data reability using Cohen's Kappa agreement. Data was analyzed describe qualitatively. The result of this research showed the content of four science literacy dimension in two biology textbooks of senior high school first grade was not spread evenly, with domination of Science as a body of knowledge. The percentage of science literacy content in book A are: 90,77 percent include of science as a body of knowledge; 5,56 percent are science as a way of investigating; 3,1 percent are science as a way of thinking; and 0,53 are science and its interaction with technology. The percentage of science literacy content in book $B$ are: 69,70 percent include of science as a body of knowledge; 12,47 percent are science as a way of investigating; 2,78 percent are science as a way of thinking; and 15,05 are science and its interaction with technology.
\end{abstract}

Keywords: content analysis, biology textbooks, science literacy.

\title{
PENDAHULUAN
}

Buku ajar sains memegang peran penting dalam kegiatan pembelajaran sains. Studi Trends in International Mathematics and Science Study (TIMSS) menyatakan bahwa sekitar $40 \%$ pembelajaran didalam kelas dilaksanakan guru dengan memanfaatkan buku ajar sains (Liu \& Khine, 2016). Buku ajar sains digunakan sebagai teks instruksional yang berguna untuk mengajarakan penggunanya karena konten didalamnya memiliki kesamaan dengan pembelajaran dikelas (Ronda \& Adler, 2016). Guru di Indonesia menggunakan setidaknya satu buku ajar untuk memberikan tugas dan pekerjaan rumah (Safitri, 2015).

Buku ajar sains merupakan terjemahan kurikulum (Cheng et. al, 2014; Binns \& Bell, 2015; Ronda \& Adler, 2016), sehingga secara detail mendefinisikan tentang apa dan bagaimana suatu materi dipelajari serta diajarkan didalam kelas sesuai kurikulum yang berlaku (Ramnarain \& Padayachee, 2015). Buku ajar sains di Indonesia juga disusun berdasarkan kurikulum saat ini (Kurikulum 2013), serta disesuaikan pada rumusan standar kompetensi lulusan (SKL) yang ingin dicapai. Rumusan SKL 
Kurikulum 2013 ini menekankan pada pendekatan saintifik yang sesuai tuntutan zaman serta sejalan dengan komponen literasi sains.

Literasi sains selama beberapa dekade terakhir dianggap sebagai permasalahan penting dunia pendidikan nasional maupun internasional. Literasi sains secara berkelanjutan diteliti melalui studi tiga tahunan Programme for International Student Assessment (PISA) (OECD, 2013). Hasil pengukuran kemampuan ini seringkali digunakan sebagai indikator global dari kualitas kesuksesan pendidikan berbagai negara serta sebagai salah satu acuan pemerintah dalam menyusun kebijakan bidang pendidikan (Meldawati, 2017). Literasi sains dianggap penting karena memahamai sains merupakan hal mendasar bagi kesiapan seseorang untuk hidup dalam masyarakat modern (Nur'aini, Rahardjo, \& Susanti, 2018). Kompetensi sains yang dimiliki peserta didik akan meningkatkan banyak keterampilan mereka dalam kehidupan sehari-hari, seperti kemampuan menyelesaikan permasalahan secara kreatif, berpikir secara kritis, bekerja dengan kooperatif dalam kelompok, dan menggunakan teknologi secara informatif dan efektif (Akcay, Ozgur Kapici, \& E. Yager, 2017). Kompetensi sains yang diterapkan dalam kehidupan sehari-hari seperti ini disebut kemampuan literasi sains (Wati, Sinaga, \& Priyandoko, 2017).

Literasi sains didalam buku ajar sains merupakan salah satu faktor yang berpengaruh dalam pembentukan pemahaman hakikat sains peserta didik (Abd-ElKhalick et al., 2017). Menurut Widowati (2017), menghadirkan literasi sains dalam proses pembelajaran memberikan hasil pengalaman yang lebih stimulatif dan keuntungan yang lebih signifikan bagi peserta didik maupun guru. Bidang pelajaran Biologi telah mengimplementasikan literasi sains yang sesuai Kurikulum 2013 melalui penjabaran tujuan pembelajaran yang meliputi: menyediakan pengalaman pembelajaran untuk memahami konsep dari biologi; proses sains; dan pemecahan permasalahan biologi sehari-hari. Implementasi kompetensi biologi ini bertujuan untuk memfasilitasi peserta didik dengan kunci pengetahuan konseptual dan pengetahuan prosedural untuk mengenalkan literasi sains didalam kegiatan pembelajaran (Suwono, Mahmudah, \& Maulidiah, 2017). Wilkinson dalam Rusilowati (2017), mengemukakan bahwa kategori literasi sains yang mendekati proporsi seimbang yaitu 42 persen untuk kategori pengetahuan sains, 19 persen penyelidikan hakikat sains, 19 persen sains sebagai cara 
berpikir, dan 20 persen interaksi sains, teknologi dan masyarakat atau secara umum memiliki perbandingan $2: 1: 1: 1$.

Buku ajar sains secara positif berkontribusi dalam mengembangkan literasi sains. Akan tetapi, beberapa hasil penelitian menunjukkan beberapa kekurangan buku ajar sains. Kekurangan tersebut diantaranya adalah kecenderungan buku ajar sains dalam menekankan pada salah satu kategori literasi sains saja. Buku ajar sains cenderung menekankan pada sains sebagai batang tubuh pengetahuan seperti fakta, konsep, prinsip, hukum, teori, model, dan mengingat informasi (Retno et al., 2017; Ariningrum, 2013). Kecenderungan ini menyebabkan peserta didik hanya bagus dalam mengingat, tetapi kurang terampil dalam menerapkan pengetahuan mereka (Ardianto \& Pursitasari, 2017). Buku ajar yang menekankan pada sains sebagai batang tubuh pengetahuan ini juga menjadi faktor kemampuan peserta didik Indonesia yang memiliki penguasaan terbatas pada konsep mendasar sains, keterbatasan pengetahuan untuk mengaplikasikan pengetahuan saintifik dalam kehidupan sehari-hari, serta kemampuan terbatas untuk menampilkan penjelasan dari fakta yang diberikan secara jelas maupun secara eksplisit (Ristanto, Zubaidah, Amin, \& Rohman, 2017).

Penelitian buku ajar sains pada umumnya berfokus pada analisis isi (content analysis) untuk menemukan muatan pengetahuan didalamnya. Menurut Chiappetta \& Fillman (2007), analisis isi tentang literasi sains didalam buku ajar sains dapat diidentifikasi menjadi empat kategori, yang meliputi: sains sebagai batang tubuh pengetahuan (science as a body of knowledge); sains sebagai jalan penyelidikan (science as a way of investigating); sains sebagai cara berpikir (science as a way of thinking); serta interaksi sains dengan teknologi dan masyarakat (science and its interaction with technology, and society).

\section{METODOLOGI PENELITIAN}

Penelitian dilaksanakan di Surakarta, sebagai tempat memperoleh objek penelitian, yaitu dua Buku Ajar Biologi kelas X dari penerbit berbeda. Teknik pengambilan objek dalam penelitian ini menggunakan sampel bertujuan (purposive sampling), yaitu teknik nonpeluang dengan pengambilan sampel yang memenuhi kriteria tertentu (Indrawan \& Yaniawati, 2014). Halaman yang digunakan ditetapkan melalui beberapa tahapan meliputi: (1) Tahap penentuan bagian buku untuk analisis, yaitu penentuan pengambilan materi bab dari buku; (2) Penentuan jumlah halaman analisis, mengikuti skala pengambilan sampel Chiappetta dan Fillman (2007), yang 
mengambil sejumlah $15 \%$ hingga $80 \%$ dari total halaman setiap bab; (3) Penetapan halaman analisis, mengikuti ketentuan Padayachee (2012) yang menetapkan halaman analilisis berdasarkan kriteria total teks (unit analisis) dalam satu halaman, muatan gambar, tabel, maupun pertanyaan-pertanyaan ulasan; (4) Penetapan halaman analisis, yaitu didapatkannya halaman-halaman untuk analisis setelah mempertimbangkan ketiga tahapan sebelumnya. Tahapan penentuan halaman yang dianalisis dapat dilihat pada Gambar 1.

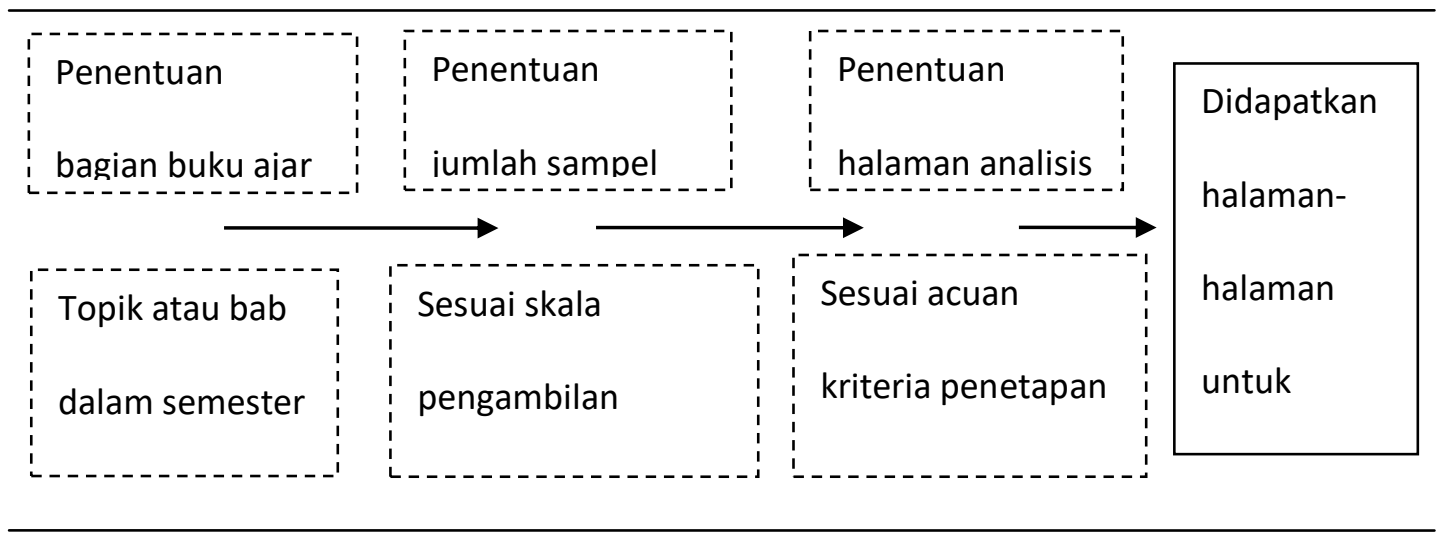

Gambar 1. Tahapan Pemilihan Halaman untuk Analisis

Penelitian ini dilakukan secara kualitatif deskriptif dengan menggunakan metode analisi isi oleh dua orang petugas koding (selanjutnya disebut coder). Coder melakukan kegiatan analisis dengan cara mengkodekan unit teks (berupa paragraf, gambar, tabel, komentar singkat, pertanyaan, dan aktivitas hands-on) kedalam kelompok kategori literasi sains yang dikodekan dari Ia (mewakili kategori I yaitu kategori sains sebagai batang tubuh pengetahuan subkategori (a) fakta, konsep, prinsip, hukum) hingga kode IVd (mewakili kategori IV yaitu kategori interaksi sains dengan teknologi dan masyarakat subkategori karir dan pekerjaan yang berhubungan dengan sains). Sebelum melakukan kegiatan koding, coder membaca dan memahami petunjuk analisis yang berupa instrumen literasi sains pada buku ajar sains yang diadaptasi dari Chiappetta \& Fillman (2007).

Validitas data pada penelitian ini dilakukan dengan uji reliabilitas inter-rater dengan mengukur koefisien Kappa. Uji ini bertujuan untuk membandingkan dan melihat konsistensi antara dua coder (inter-rater agreement) dalam memberikan nilai berupa kode terhadap unit teks yang dianalisis. Disamping uji konsistensi Kappa, untuk melihat konsistensi data dilakukan juga pengukuran persentase kesepakatan antar coder. Interpretasi nilai koefisien Kappa pada Tabel 1. 
Tabel 1. Interpretasi nilai Kappa

\begin{tabular}{ll}
\hline Besarnya nilai k & Kesepakatan \\
\hline$<0$ & Sangat Rendah/ Lemah (Poor) \\
$0,01-0,20$ & Rendah (slight) \\
$0,21-0,40$ & Cukup (Fair) \\
$0,41-0,60$ & Sedang (moderate) \\
$0,61-0,80$ & Kuat (substantial) \\
$0,81-0,99$ & Hampir sempurna (almost perfect) \\
\hline
\end{tabular}

\section{HASIL DAN PEMBAHASAN}

Berdasarkan analisis data hasil penelitian, indeks kesepakatan pada masingmasing coder menunjukkan bahwa nilai persentase kesepakatan yang terukur bernilai diatas 77 persen, yang artinya kedua coder menilai sebanyak lebih dari 77 persen unit analisis dengan nilai pengkodean yang sama (sepakat). Menurut Aldahmash et al. (2016), nilai kappa diterima apabila berada pada rentang 0,40 hingga 0,75. Statistik kappa Buku A dan Buku B berada pada nilai 0,43 hingga 0,95 yang artinya kesepakatan antar coder berada pada tingkat sedang, kuat, serta hampir sempurna. Hasil perhitungan statistik Kappa dan persentase kesepakatan dapat dilihat pada Tabel 2.

Tabel 2. Nilai Kesepakatan dan Statistik Kappa antar coder

\begin{tabular}{lllll}
\hline \multirow{2}{*}{ Bab } & Buku A & \multicolumn{3}{c}{ Buku B } \\
\cline { 2 - 5 } & \% Kesepakatan & Kappa & \% Kesepakatan & Kappa \\
\hline Ruang Lingkup Biologi & 87,09 & 0,73 & 88,89 & 0,82 \\
Keanekaragaman Hayati & 77,42 & 0,43 & 91,30 & 0,77 \\
Virus & 93,75 & 0,78 & 93,10 & 0,64 \\
Bakteri & 85,71 & 0,64 & 91,89 & 0,95 \\
Protista & 92,59 & 0,79 & 96,67 & 0,78 \\
Jamur & 86,65 & 0,65 & 94,44 & 0,87 \\
\hline
\end{tabular}

Hasil analisis literasi sains yang berpedoman pada empat kategori yang ditetapkan Chiappetta dan Fillman (2007) dari kedua Buku Ajar Biologi kelas X Semester Ganjil pada penelitian ini dapat dilihat pada tabel 3.

Tabel 3 Persentase sebaran literasi sains untuk setiap buku

\begin{tabular}{|c|c|c|c|c|}
\hline \multirow{2}{*}{ No } & \multirow{2}{*}{ Kategori Literasi Sains } & \multicolumn{2}{|c|}{ Persentase sebaran $(\%)$} & \multirow{2}{*}{$\begin{array}{l}\text { Rata-rata } \\
(\%)\end{array}$} \\
\hline & & Buku A & Buku B & \\
\hline 1 & $\begin{array}{l}\text { Sains sebagai batang tubuh } \\
\text { pengetahuan }\end{array}$ & 90,77 & 68,76 & 79,76 \\
\hline 2 & Sains sebagai jalan penyelidikan & 5,56 & 12,83 & 9,19 \\
\hline 3 & Sains sebagai cara berpikir & 3,1 & 2,78 & 2,94 \\
\hline 4 & $\begin{array}{l}\text { Interaksi sains dengan teknologi dan } \\
\text { masyarakat }\end{array}$ & 0,53 & 15,63 & 8.08 \\
\hline
\end{tabular}


Berdasarkan Tabel 3 dapat diketahui bahwa keempat kategori literasi sains menunjukkan persentase yang berbeda. Persentase rata-rata buku A dan B pada kategori sains sebagai batang tubuh pengetahuan sebanyak 76,76\%; 9,19\% pada kategori sains sebagai jalan penyelidikan; $2,94 \%$ berada pada sains sebagai cara berpikir; dan sisanya berada pada interaksi sains dengan teknologi dan masyarakat sejumlah 8,08\%.

Penelitian ini menunjukkan bahwa besarnya persentase penemuan kategori sains sebagai batang tubuh pengetahuan dibandingkan tiga kategori lainnya. Hasil ini tidak berbeda dengan hasil penelitian serupa yang dilakukan oleh Chiappetta \& Fillman (2007) yang melakukan analisis pada lima buku Biologi di Amerika maupun hasil penelitian dari Ramnarain \& Padayachee (2015) yang melakukan analisis perbandingan muatan literasi sains pada buku Biologi di Afrika. Keduanya menyatakan bahwa kategori sains sebagai batang tubuh pengetahuan pada penelitian paling banyak muncul pada buku ajar biologi yang mereka teliti. Kategori sains sebagai batang tubuh pengetahuan mewakili dasar-dasar pengetahuan seperti fakta, konsep, hukum, teori, hipotesis, model, dan lain-lain.

Berdasarkan hasil penelitian, terjadinya kecenderungan yang lebih menekankan pada kategori ini akan berimbas menyebabkan peserta didik hanya bagus dalam mengingat, tetapi kurang terampil dalam menerapkan pengetahuan mereka, ini mungkin terkait dengan kecenderungan untuk menggunakan daya ingat sebagai alat untuk menguasai sains, bukan kemampuan untuk berpikir (Ardianto \& Pursitasari, 2017). Hal ini menjadi salah satu penyebab rendahnya kemampuan literasi sains peserta didik Indonesia yang mana peserta didik memiliki penguasaan terbatas pada konsep mendasar sains, keterbatasan pengetahuan untuk mengaplikasikan pengetahuan saintifik dalam kehidupan sehari-hari, serta kemampuan terbatas untuk menampilkan penjelasan dari fakta yang diberikan secara jelas maupun secara eksplisit (Ristanto, Zubaidah, Amin, \& Rohman, 2017). Pemberian materi lebih mementingkan pengetahuan saja sehingga siswa pandai menghapal tetapi kurang terampil dalam mengaplikasikan pengetahuan yang dimilikinya. Hal ini kemungkinan terkait dengan kecenderungannya menggunakan hafalan sebagai wahana menguasai ilmu pengetahuam, bukan kemampusn berpikir (Maturradiya dkk, 2015). Kategori ini menunjukkan bahwa buku ajar biologi yang dianalisis ditujukan untuk memenuhi pengetahuan konten. 
Beberapa topik biologi, tidak mengarahkan pada perlakuan seimbang terkait keempat kategori literasi sians. Meskipun demikian, jika sejumlah besar halaman buku dianalisis, seharusnya terlihat jelas bagi peneliti dan siswa, bahwa biologi lebih dari sekedar hanya menghadirkan pengetahuan faktual. Secara teori memang tidak ada ketentuan standar yang mengatur ruang lingkup kategori indikator literasi sains pada buku ajar sains. Namun apabila komposisi penyajian kategori indikator pengetahuan sains (konten, sains) lebih dominan dibandingkan kategori indikator literasi sains lainnya, maka dikhawatirkan peserta didik akan kurang berkembang dalam membangun pengetahuannya sendiri dan melakukan penyelidikan terhadap fenomena-fenomena sains. Ketika proses sains peserta didik rendah, maka dimungkinkan peserta didik akan emngalami kesulitan dalam menempatkan sains di kehidupan nyata, sehingga kemampuan dalam memahami interaksi sains dan teknologi terhadap masyarakat tidak akan berkembang secara maksimal (Sandi dkk, 2014). Oleh karena itu, penting untuk mengembangkan bahan ajar biologi yang berkualitas untuk meningkatkan kemampuan literasi sains peserta didik yang mencakup dimensi konten, proses, dan konteks. Bahan ajar yang berkualitas akan mempengaruhi tidak hanya kemampuan literasi sains peserta didik saja yang akan meningkat, tetapi motivasi dan semangat belaajr peserta ddidik terhadap mata pelajaran juga akan meningkat (Ardina dkk, 2017).

Buku ajar yang dapat menunjang pembelajaran, yang tidak hanya menekankan pengetahuan sains saja, tetapi harus mencakup kategori literasi sains secara seimbang. Seperti yang dikemukakan oleh Leonard (1993), bahwa pelajaran sains sebaiknya lebih menekankan kepada aktivitas siswa, mengurangi kegiatan mengingat pengetahuan berupa fakta-fakta, lebih menekankan keterampilan proses sains untuk mendapatkan konsep, siswa belajar aktif dan sebagian besar waktu siswa dihabiskan di laboratorium atau kerja lapangan (Maturradiah dkk, 2015)

Bahan ajar memegang peranan penting dalam proses pembelajaran, yaitu sebagai media penyampaian informasi. Dengan demikian dibutuhkan bahan ajar yang baik agar tujuan pembelajaran dicapai secara maksimal. Bahan ajar yang baik adalah bahan ajar yang memuat komponen literasi sains secara seimbang. Wilkinson, dalam Paramita (2017) mengemukakan kategori literasi sains yang mendekati prooprsi seimbang yaitu $42 \%$ untuk kategori pengetahuan sains, $19 \%$ penyelidikan hakikat sains, $19 \%$ kategori sebagai cara berpikir, dan 20\% interaksi sains, teknologi, dan masyarakat. 
Mengembangkan kemampuan siswa dalam mengkonstruk konsep tidak dapat dilakukan secara spontan. Agar dapat mengembangkan suatu peta konsep, mahasisw perlu diberi latihan atau pembiasaan terlebih dahulu. Eggen (2012) juga menyatakan bahwa semakin sering siswa belajar tentang satu topic, semakin baik mereka mampu berpikir tentang topik itu. dengan demikian, semakin sering siswa dihadapkan pada soal analisis dan penggunaan konsep maka semakin baik pula kemampuan mereka (Paramita, Rusilowati, 2017).

\section{SIMPULAN}

Berdasarkan analisis hasil penelitian, diketahui bahwa buku Biologi untuk SMA kelas X semester ganjil berdasarkan kategori literasi sains Chiappetta dan Fillman yaitu ditemukan persentase sebaran paling banyak pada kategori sains sebagai batang tubuh pengetahuan.Hasil analisis literasi sains Buku A yaitu: sains sebagai batang tubuh pengetahuan sebesar 90,77 persen; sains sebagai jalan penyelidikan sebesar 5,56 persen; sains sebagai cara berpikir sebesar 3,1 persen; serta interaksi sains dengan teknologi dan masyarakat sebesar 0,53 persen. Hasil analisis literasi sains Buku B yaitu: sains sebagai batang tubuh pengetahuan sebesar 69,70 persen; sains sebagai jalan penyelidikan sebesar 12,47 persen; sains sebagai cara berpikir sebesar 2,78 persen; serta interaksi sains dengan teknologi dan masyarakat sebesar 15,05 persen.

\section{DAFTAR PUSTAKA}

Abd-El-Khalick, F., Myers, J. Y., Summers, R., Brunner, J., Waight, N., Wahbeh, N., ... Belarmino, J. (2017). A longitudinal analysis of the extent and manner of representations of nature of science in U.S. high school biology and physics textbooks. Journal of Research in Science Teaching, 54(1), 82-120. http://doi.org/10.1002/tea.21339

Akcay, H., Ozgur Kapici, H., \& E. Yager, R. (2017). Using Newspapers and Advertisement as a Focus for Science Teaching and Learning. Universal Journal of Educational Research, 5(1), 99-103. http://doi.org/10.13189/ujer.2017.050112

Ardianto, D., \& Pursitasari, I. D. (2017). Do Middle School Science Textbook Enclose an Entity of Science Literacy?, 1(1), 24-27.

Ariningrum, T. R. (2013). Analisis literasi ilmiah buku teks pelajaran biologi sma. Universitas Negeri Semarang. 
Binns, I. C., \& Bell, R. L. (2015). Representation of Scientific Methodology in Secondary Science Textbooks. Science \& Education, 24(7-8), 913-936. http://doi.org/10.1007/s11191-015-9765-7

DiGiuseppe, M. (2014). Representing Nature of Science in a Science Textbook: Exploring author-editor-publisher interactions. International Journal of Science Education, 36(7), 1061-1082. http://doi.org/10.1080/09500693.2013.840405

Cheng, M., Chou, P., Wang, Y., \& Lin, C. (2014). Learning effects of a science textbook designed with adapted cognitive process principles on grade 5 students, (October 2013).

Liu, Y., \& Khine, M. S. (2016). Content Analysis of The Diagrammatic Representations of Primary Science Textbooks. EURASIA Journal of Mathematics, Science \& Technology Education, 12(8), 1937-1951. http://doi.org/10.12973/eurasia.2016.1288a

Maturradiyah, N., rusilowati, A. (2015). Analisis Buku Ajar Fisika SMA Kelas XII di Kabupaten Pati Berdasarkan Muatan Literasi Sains. Unnes Physics Education Journal. http://journal.unnes.ac.id/sju/index.php/upej

Meldawati. (2017). Building Students 'Scientific Literacy through Contextual Learning in the Physics Classroom. University of Tampere.

Nur'aini, D., Rahardjo, S. B., \& Susanti, V. H. E. (2018). Student' s profile about science literacy in Surakarta. Journal of Physics: Conf. Series 1022 01206, 1-6.

OECD. (2013). PISA 2015 DRAFT SCIENCE FRAMEWORK, (March 2013), 1-54.

Padayachee, K. (2012). A study on the analysis and use of Life Sciences textbooks for the nature of science.

Paramita, A. D., Rusilowati, A. (2017). Pengembangan Bahan Ajar Berbasis Literasi Sains Materi Suhu dan Kalor, 500, 58-67.

Ramnarain, U., \& Padayachee, K. (2015). A comparative analysis of South African Life Sciences and Biology textbooks for inclusion of the nature of science, 35(1), 18.

Retno, A. T. P., Saputro, S., \& Ulfa, M. (2017). KAJIAN ASPEK LITERASI SAINS PADA BUKU AJAR KIMIA SMA KELAS XI DI KABUPATEN BREBES. Seminar Nasional Pendidikan Sains (SNPS) 2017, 21(2013), 112-123.

Ristanto, R. H., Zubaidah, S., Amin, M., \& Rohman, F. (2017). Scientific Literacy of Students Learned Through Guided Inquiry. International Journal of Research and Review, 4(May), 23-30.

Ronda, E., \& Adler, J. (2016). Mining Mathematics in Textbook Lessons. International Journal of Science and Mathematics Education. http://doi.org/10.1007/s10763016-9738-6

Suwono, H., Mahmudah, A., \& Maulidiah, L. (2017). Scientific Literacy of a Third Year Biology Student Teachers: Exploration Study, 2017(2016), 269-278. http://doi.org/10.18502/kss.v1i3.747

Wati, F., Sinaga, P., \& Priyandoko, D. (2017). Science Literacy: How do High School Students Solve PISA Test Items? Journal of Physics: Conf. Series 895 012166, $1-6$. 